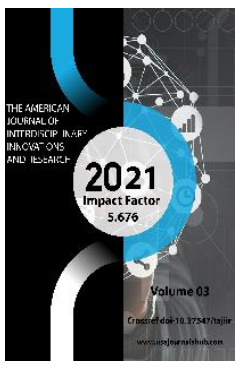

Journal Website: https://theamericanjou rnals.com/index.php/ta jiir

Copyright: Original content from this work may be used under the terms of the creative commons attributes 4.0 licence.

\section{Experience Of Cambridge Curricula In Ensuring The Continuity Of Curricula In The Field Of "Computer Science And Information Technology" In The System Of Professional Education}

\author{
Juraev Muzaffarjon Mansurjonovich \\ Lecturer Of The Department Of Informatics, Faculty Of Physics And Mathematics, Kokand \\ State Pedagogical Institute Named After Muqimi, Kokand, Uzbekistan
}

\title{
ABSTRACT
}

This article highlights about introducing students to the basics of science, the general principles of human activity, the formation of general, digital and material culture, the acquisition of specific skills, as well as finding innovative solutions to practical problems based on digital technologies in vocational education institutions and the experience of world-renowned, world-renowned, and successfully implemented curricula will play an important role in its implementation. In particular, the Cambridge International General Certificate of Secondary Education curricula are among them.

\section{KEYWORDS}

The Cambridge International General Certificate Of Secondary Education Curricula, Information Technology, Assessment.

\section{INTRODUCTION}

Cambridge International General Certificate of Secondary Education (Cambridge IGCSE) curriculum international skills are recognized by the best universities and employers in the world, providing students with a wide range of opportunities to study and choose a career. As a non-profit organization, Cambridge
Assessment International Education is devoting its resources to providing high quality educational programs that unlock the potential of its students.

The Cambridge IGCSE curriculum sets global standards for international education. They are created by science experts, who are based on 
academic perseverance, and reflect recent academic research. They provide a powerful platform for students to move from one stage to the next and help them with learning resources.

\section{MATERIALS AND METHODS}

Cambridge's approaches encourage students to:

- Confident - the use of a number of technologies and programming paradigms

- Responsible - the ethical use of technology

- Reflective - improve their programming solutions as programmers

- Innovative - effective problem solving

- Engaged - how it is built and how software solutions are developed.

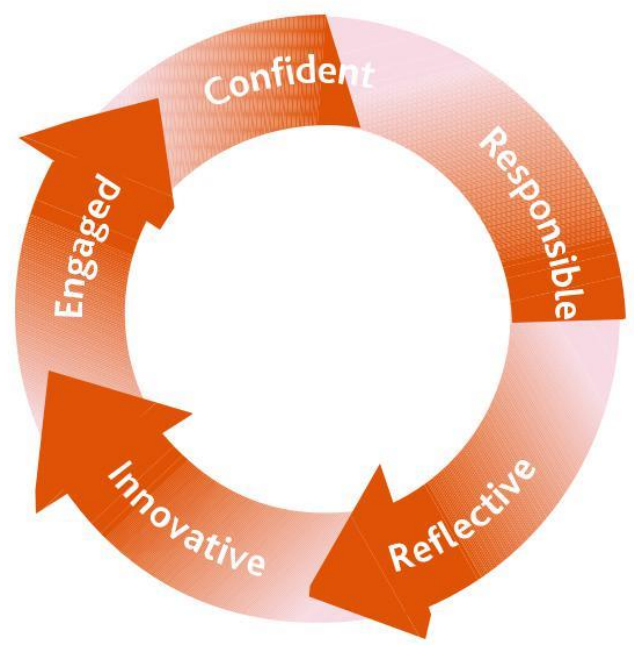

Let us first answer the question of what kind of program the Cambridge IGCSE Computer Science itself is. Cambridge IGCSE Computer Science is the ideal foundation for further work in Informatics. Understanding the basics of computer science will provide students with the knowledge they need for other sciences and engineering disciplines, and the skills learned will be able to apply them in daily life as well.

The purpose of the Cambridge IGCSE Computer Science curriculum is as follows:

- Computational thinking involves thinking about what can be calculated and how to calculate, and reviewing the information needed

- To understand the basic principles of problem solving using computers

- To understand that every computer system is made up of subsystems

- To understand the components of computer systems and their interrelationships, including software, data, hardware, and communications

- To acquire the skills needed to apply concepts in solving computer-based problems using a high-level programming language.

Cambridge IGCSE Computer Science programs balance thorough knowledge and understanding of a topic and help students develop the skills they need for their next steps in their studies or employment.

Students who study on the basis of the Cambridge IGCSE Computer Science curriculum - learn the principles and practices of computing and gain confidence in computational thinking and programming. They learn programming by writing computer code and develop an understanding of the basic principles of solving problems using computers. Students use their concepts to solve problems on a computer-based basis using algorithms and a high-level programming 
language. They also develop a range of technical skills and the ability to evaluate computational solutions. This skill will help students understand modern and evolving computing technologies and the benefits of using them. They learn how to deal with ethical issues and potential dangers while using computers.

The combination of knowledge and skills in the Cambridge IGCSE Computer Science programs provides students with a solid foundation for future study. Candidates who have achieved existing levels from $A$ * to $C$ are recommended to pursue many majors, such as Cambridge International AS\&A Level Computer Science.

Cambridge IGCSE Computer Science programs are recognized and appreciated by the world's leading universities and employers as proof of scientific achievement. Most universities require a Cambridge International AS\&A Level Computer Science certificate that meets admission requirements.

The Cambridge International AS\&A Level curriculum envisages approximately 180 hours of course time for each AS Level and approximately 360 hours for A Level.

\section{AS degree structure}

Sections 1 to 8 of the AS degree curriculum: Computational thinking is developed using an approach that includes the use of programming and problem-solving skills to solve real-life problems. This requires managing and storing various types of data and transmitting solutions over the network. Computational thinking is aided by developing an understanding of how computer architecture, hardware, system software, security measures, and communication systems provide the necessary infrastructure efficiently and ethically. The curriculum supports opportunities for students to apply their skills in the practical contexts required in the digital field.

\section{A degree structure}

Level A Computational Thinking is further developed to expand the methods of searching, sorting, compiling, and storing information in sections 9 through 12 of the Level A curriculum. This includes the concept of artificial intelligence. Programming paradigms involve working with recursion and projects, along with expanding programming skills. The development of in-depth understanding of computer architecture, hardware, system programs, security measures, and the fact that communication systems have different structures and protocols is done on the basis of calculations. These can be combined to provide the appropriate infrastructure to solve problems. The curriculum provides students with the opportunity to apply the practical skills required in the digital field.

\section{A Level}

This level assesses the practical application of sections 13 to 20 in the curriculum. Programming tasks are based on a small number of scenarios, where candidates assess the ability to write programs or program elements. The centers should ensure that all candidates have access to computers belonging to the center and that they do not have access to the Internet or e-mails. 
The above analysis shows that the knowledge, skills and abilities of students in the field of Informatics and Information Technology in vocational education institutions of our country should correspond to the A Level level of the Cambridge International AS\&A Level curriculum. Below, we review the order in which students who have mastered the Cambridge International AS\&A Level curriculum assess the knowledge, skills, and competencies they need to acquire, and

1- Assessment
Fundamentals of
Theory

1 hour 30 minutes

75 points

Assessment 1 assesses sections 1 to 8 of the curriculum. Written work. Externally evaluated. Candidates will answer all questions. $50 \%$ of AS level $25 \%$ of level A 2- Assessment Basic problemsolving and programming skills

\section{2 hours}

75 points

In the 2nd assessment, sections 9 to 12 of the curriculum are assessed. explore the conclusions we need to make for ourselves.

The document provided by Cambridge International must be kept with the center number, the candidate's name, and the candidate's number. At each stage of the 4th assessment, candidates will be asked to copy program lists or include a screenshot of the results in the evidence document. If there is no evidence of the case in the supporting document, the case will have no significance. 


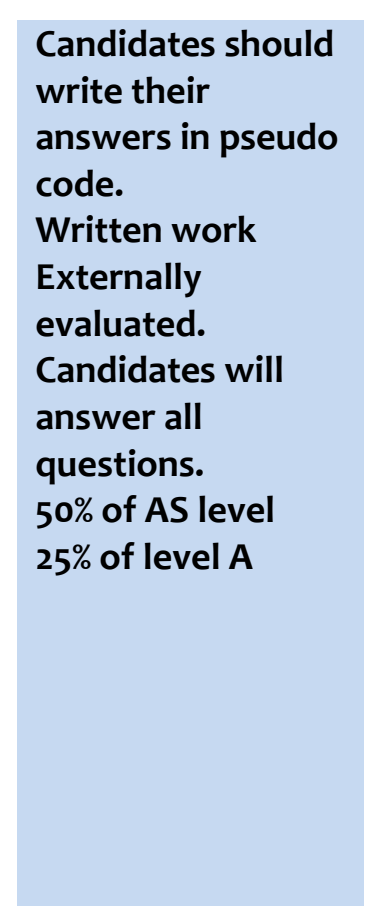

The analysis of assessment methods of Cambridge International AS\&A Level curricula shows that they focus on solving certain problems in the control of knowledge, skills and abilities of students in the field of Informatics and Information Technology in Primary Vocational Education, based on practical processes or specializations of students. These cases should be used. In this way, the student's ability to apply effectively the knowledge gained in this subject in their future work is also jointly assessed.

We can obtain the necessary analysis and conclusions by comparing the curriculum of "Computer Science and Information

program code
and test
assignment
solutions.
Candidates are
required to use
JAVA, VB NET or
Phyton
programming
languages.
Externally
evaluated.
Candidates will
answer all
questions on the
Internet or on a
computer without
email.
$25 \%$ of level A

Technology" in primary vocational education institutions of our country with the Cambridge IGCSE Computer Science curriculum within the Cambridge IGCSE international programs.

Based on the topics that students need to master in the Cambridge IGCSE Computer Science curriculum, we analyzed the requirements for the knowledge skills and competencies that students need to acquire. As a result, we have formulated the content of the curriculum in the field of informatics and information technology in primary vocational education institutions in our country as follows:

Table 1. Content of professional education curriculum

\begin{tabular}{|c|c|}
\hline № & Name of topics \\
\hline & Spreadsheets \\
\hline & Processing video files \\
\hline & Programming in Phyton \\
\hline & Artificial intelligence \\
\hline & 3D modeling \\
\hline
\end{tabular}




\begin{tabular}{|l|c|}
\hline & Web design. CSS \\
\hline & Computer hardware and software \\
\hline & Network technology \\
\hline & Working with databases \\
\hline & IoT (internet of things) technologies \\
\hline & IT startup projects \\
\hline
\end{tabular}

Formed through the analysis of the Cambridge IGCSE Computer Science curriculum, the content of this Primary Vocational Education Institutions Informatics and Information Technology curriculum is designed to conduct research in classroom and extracurricular activities to demonstrate the relevance of students' knowledge, skills and competencies in everyday life. They focuse creativity, developing an interest in creating innovations. The education system in our country requires radical reform of the principles, content, forms and methods of the educational process at the level of the requirements of new educational technologies.

\section{RESULTS}

Based on the analysis of Cambridge International's educational programs and skills in general secondary schools and vocational education institutions in the teaching of computer science and information technology, the current state of computer science education and the accumulated experience, we can make a number of recommendations:

- Summarize the experience of current curricula and Cambridge IGCSE Computer Science curricula in the formation of digital literacy and culture, critical thinking and creative information and communication competencies that can be applied in independent life, the content of current computer science and information technology taught in vocational education institutions;

- Effective use of the experience of Cambridge IGCSE Computer Science curricula in the teaching of computer science and information technology to ensure interdisciplinary competencies and interdisciplinary connectivity;

- Effective use of Cambridge IGCSE Computer Science textbooks and manuals in the development of teaching materials for computer science and information technology;

- Inclusion in the Cambridge IGCSE Computer Science curriculum of elements necessary for the development of the economy of Uzbekistan, such as educational content management systems, completeness, computational mathematics, social networks, ecommerce, digital information processing and processing technologies;

- Formation of teaching methods, didactics, software, equipment and facilities aimed at developing the necessary competencies for the transition to the next stage of education, incorporating the experience of Cambridge IGCSE Computer Science curricula into the content of applied informatics and information technology taught in vocational education institutions. 


\section{CONCLUSION}

Based on these recommendations - to teach students the subject of "Computer Science and Information Technology" in primary vocational education on the basis of Cambridge international educational programs and skills, to introduce students to the basics of science, the general principles of human activity, general, digital and material culture , mastering their unique skills, as well as finding and implementing innovative solutions to practical problems based on digital technologies.

\section{REFERENCES}

1. Вяземский Е. Е. Современная система образования в Великобритании//Проблемы современного образования. 2010. № 6. С. 68-84.

2. Начальное и среднее образование Великобритании.

URL:http://www.activegroup.kg/syste $\mathrm{m} / 128$. html.

3. З.Образование в Великобритании. URL:

http://www.studinter.ru/text_obrazov anie_gb.html

4. Макарова Т.Е. Опыт взаимодействия педагогов с родителями воспитанников в дошкольных учреждениях США // Детский сад: теория и практика. 2015. № 11 (59). С. 108-112

5. Макарова Т.Е. Партнерские программы муниципальных властей США в образовании // Профессиональное образование. Столица. 2015. № 12. С. 36-38
6. Макарова Т.Е., Макаров Е.П. Социально-педагогическая деятельность религиозных организаций // В сборнике: Российская наука: тенденции и возможности Сборник научных статей. Научный ред. Л.И. Ермакова. москва, 2018. С. 57-61

7. Судоргина Л. В. Образовательная система современной школы (взгляд из России и Великобритании) // Вестник Новосибирского государственного педагогического университета. 2014. № 2 (18). С. 7-16.

8. Система школьного образования в Великобритании. URL: http://www.edemvlondon.ru/schoolsystemin-england.html.

9. Корень А.В. Использование электронной образовательной среды Moodle в создании интерактивных учебных курсов нового поколения // Территория новых возможностей. Вестник Владивостокского государственного университета экономики и сервиса. 2013. - №3 (21). -С. 127-138.

10. Образование за рубежом: от А и до Я [Электронный ресурс]. - Режим доступа. -URL: http://www.kznaniam.ru/uk (дата обращения 01.09.2021) 